Brazilian Journal of Microbiology (2009) 40: 601-611

ISSN 1517-8382

\title{
MICROBIAL MODELING OF THERMAL RESISTANCE OF ALICYCLOBACILLUS ACIDOTERRESTRIS CRA7152 SPORES IN CONCENTRATED ORANGE JUICE WITH NISIN ADDITION
}

\author{
Wilmer Edgard Luera Peña*1 ${ }^{1}$ Pilar Rodriguez de Massaguer ${ }^{2}$, Luciano Quintão Teixeira ${ }^{1}$ \\ ${ }^{1}$ Universidade Federal do Espírito Santo, Centro de Ciências Agrárias \\ Departamento de Engenharia Rural, Alegre, ES, Brasil; ${ }^{2}$ Universidade Estadual de Campinas, Departamento de Ciências de \\ Alimentos, Campinas, SP, Brasil
}

Submitted: September 08, 2008; Approved: May 03, 2009.

\begin{abstract}
The nisin effect on thermal death of Alicyclobacillus acidoterrestris CRA 7152 spores in concentrated orange juice $\left(64^{\circ} \mathrm{Brix}\right)$ was studied. Concentrations of $0,50,75$ and $100 \mathrm{IU}$ of nisin/ml juice, at temperatures of $92,95,98$ and $102^{\circ} \mathrm{C}$ were evaluated. The quadratic polynomial model was used to analyze the effects of the factors and their interaction. Verification of surviving spores was carried out through plating in $\mathrm{K}$ medium ( $\mathrm{pH}$ 3.7). The results showed that the $\mathrm{D}$ values without nisin addition were $25.5,12.9,6.1$ and $2.3 \min$ for $92,95,98$ and $102^{\circ} \mathrm{C}$ respectively. With addition of nisin into the juice there was a drop of heat resistance as the concentration was increased at a same temperature. With 30, 50, 75,100 and $150 \mathrm{IU} / \mathrm{ml}$ at $95^{\circ} \mathrm{C}$, the $\mathrm{D}$ values were $12.34,11.38,10.49,9.49$ and 9.42 min respectively, showing that a decrease in the D value up to $27 \%$ can be obtained. The second order polynomial model established with $r^{2}=0.995$ showed that the microorganism resistance was affected by the action of temperature followed by the nisin concentration. Nisin therefore is an alternative for reducing the rigor of the A. acidoterrestris CRA 7152 thermal treatment.
\end{abstract}

Key words: Alicyclobacillus acidoterrestris, orange juice concentrate, modeling, nisin

\section{INTRODUCTION}

The pasteurization of acid fruit juices at temperatures between 85 and $95^{\circ} \mathrm{C}$ kills non-sporeforming microorganisms such as yeasts, molds and some non-sporeforming bacteria. However bacterial spores can survive and germinate on acid conditions (3). Alicyclobacillus, a microorganism that causes "off-flavor" in fruit juice, became a new indicator of quality for these products. Is a non-pathogenic, thermoacidophilic, spore forming bacteria, which isolated and identified from forest soil as well as from several fruit juices pasteurized and contaminated (27). Different D values for this microorganism

*Corresponding Author. Mailing address: Universidade Federal do Espírito Santo, Centro de Ciências Agrárias

Departamento de Engenharia Rural, CP 16, CEP 29500-000, Alegre, ES, Brazil.; Tel: +552835528988.; E-mail: edgard@cca.ufes.br 
were reported in the literature depending on the strain and the form of heating: 50 and $2.7 \mathrm{~min}$ at temperatures of 85 and $95^{\circ} \mathrm{C}$ respectively (7), 23 and $16 \mathrm{~min}$ at $90^{\circ} \mathrm{C}$ in apple juice with $11.4{ }^{\circ}$ Brix and grape juice with $15.8{ }^{\circ}$ Brix respectively (23), 1.4, 4.8 and 19.9 min at 95,90 and $87^{\circ} \mathrm{C}$ respectively, in passion-fruit juice with $12^{\circ} \mathrm{Brix}$ and $\mathrm{pH} 3.12$ (13).

Pontius et al. (18) studied the effect of different acids (citric, tartaric and malic) on heat resistance of $A$. acidoterrestris spores, showing that the $\mathrm{D}$ value changed with the $\mathrm{pH}$ change at low temperatures $\left(88^{\circ} \mathrm{C}\right)$, but the effect was less evident at high temperatures. Silva et al. (22) showed that the heat resistance of $A$. acidoterrestris was affected by the temperature, followed by soluble solids concentration and $\mathrm{pH}$, using laboratory medium; the found model did not make good predictions when used in food systems, indicating that a model established from data produced in laboratory media cannot be used directly to estimate heat resistance in foods. Heat resistance is a characteristic of food spoiling microorganisms and highly influenced by the form of heating, being this information important for designing pasteurization processes.

The antibacterial polypeptide nisin has great effect against gram-positive bacteria (5), and it can be an addictive effect to the thermal treatment that inactivates these microorganisms, when employed together with heating (1). Some studies have already been carried out with bacterial spores. The presence of nisin during heating increased the mortality of spores of Bacillus cereus and A. acidoterrestris $(2,11,16,28)$. Yamazaki et al. (30) obtained up to $24 \%$ reduction in the $\mathrm{D}$ value at $90^{\circ} \mathrm{C}$ using $200 \mathrm{IU}$ nisin $/ \mathrm{ml}$ in orange drinks.

The orange concentrate from different provenances, which it is traded in great amounts in the world market, showed presence of viable Alicyclobacillus spores up to $6.4 \mathrm{x}$
$10^{2} \mathrm{UFC} / \mathrm{ml}$ (17). Studies of spore inactivation in this product become therefore very important in order to reduce this initial spore load, since after reconstituting the juice (approximately $11^{\circ}$ Brix), it becomes susceptible to deterioration by this microorganism.

The objective of this work was to study the effect of pasteurization temperature $\left(92\right.$ to $\left.102^{\circ} \mathrm{C}\right)$ and nisin concentration ( 0 to $100 \mathrm{IU} / \mathrm{ml}$ ) on the thermochemical resistance indicated by the $\mathrm{D}$ value of $A$. acidoterrestris in concentrated orange juice ( $64^{\circ}$ Brix) using the quadratic model to analyze the two factors and their possible interactions.

\section{MATERIALS AND METHODS}

\section{Bacterial strain and culture medium}

Alicyclobacillus acidoterrestris CRA 7152 strain and nisin were provided by Danisco Cultor.

Sporulation agar: Alicyclobacillus acidocaldarius medium (AAM) (14): 0.05\% $\mathrm{MnCl}_{2} 4 \mathrm{H}_{2} \mathrm{O} ; 1.5 \%$ agar; $1.0 \mathrm{~g}$ Yeast extrac (Oxoid, Basingstoke, UK); $0.2 \mathrm{~g} \quad\left(\mathrm{NH}_{4}\right)_{2} \mathrm{SO}_{4}$; $0.5 \mathrm{~g} \mathrm{MgSO}_{4} 7 \mathrm{H}_{2} \mathrm{O} ; 0.25 \mathrm{~g} \mathrm{CaCl}_{2} 2 \mathrm{H}_{2} \mathrm{O} ; 0.60 \mathrm{~g} \mathrm{KH}_{2} \mathrm{PO}_{4}, 1.0$ $\mathrm{g}$ glucose (Oxoid) and $1000 \mathrm{ml}$ water. $\mathrm{pH}$ was adjusted to 4.0.

Quantification medium K: Peptone, 5 g (Oxoid); Glucose $1 \mathrm{~g}$ (Oxoid); Yeast extract $2.5 \mathrm{~g}$ (Oxoid); Tween-80 $1 \mathrm{~g}$ (Synth); Agar 15 g (Difco laboratories, Detroit, MI); Distilled water $1000 \mathrm{ml}$. Medium was sterilized at $121^{\circ} \mathrm{C}$ for 15 minutes and $\mathrm{pH}$ adjusted to 3.7 with malic acid (Vetec) at $25 \%$ sterilized by filtration (26).

\section{Spore suspension preparation}

Initially the growth of viable Alicyclobacillus acidoterrestris cells was produced in 4 slant tubes containing 
Potato Dextrose Agar, pH 5.6 (PDA-Oxoid), incubated at $44^{\circ} \mathrm{C}$ for 3 days. After that, the result of growth was collected from tubes by scraping the bottle with sterile glass rods using $5 \mathrm{ml}$ sterile distilled water per tube. The suspension produced was transferred to a sterile screw caped tube $(25 \times 200 \mathrm{~mm})$, and activated at $80^{\circ} \mathrm{C}$ for 10 minutes, followed by fast cooling in ice bath until room temperature. A portion $(0.1 \mathrm{ml})$ of activated suspension was inoculated on each of 100 glass bottles $(290 \mathrm{ml})$ containing $60.0 \mathrm{ml}$ of solidified and slanted medium (AAM) (30). Those 100 inoculated bottles inoculated were incubated during 9 days at $45.0^{\circ} \mathrm{C}$. After $90 \%$ sporulation of the field confirmed by microscopic observation of spore stain, spore collection was carried out (14). Collected spores were washed and resuspended in sterile distilled water after 3 centrifugations $(12310 \mathrm{~g} / 15 \mathrm{~min}$ at $4^{\circ} \mathrm{C}$ ), followed by alternate washing. Lysozime at 0.3 $\mathrm{mg} / \mathrm{ml}$ suspension was added after the first washing, after $\mathrm{pH}$ adjustment to 11 for disruption of vegetative cells (24). Spores suspension was stored at $4^{\circ} \mathrm{C}$ in sterile distilled water until its use. Spores count was performed in $\mathrm{K}$ medium after thermal activation for 10 minutes at $80^{\circ} \mathrm{C}$, followed by pour plating. The inverted plates were incubated at $43^{\circ} \mathrm{C}$ for 5 days. Concentration of spores suspension was $8 \times 10^{8}$ spores $/ \mathrm{ml}$.

\section{Experimental design}

Thermal death kinetics of A. acidoterrestris spores suspension in concentrate orange juice were carried out by sealed thermal-death-time (TDT) tube method according to Stumbo (24). The thermal lag for each temperature was determined with a TDT tube holding $2 \mathrm{ml}$ of concentrate orange juice and with a flexible tube $\mathrm{T}$ thermocouple duplex Omega TT-36 wire (Omega, Bridgeport, NJ).

Initially, different nisin concentrations were tested in order to determine the maximum concentration that minimizes the $\mathrm{D}$ values for bacterium. D values were determined at $95^{\circ} \mathrm{C}$ with $0,30,50,75,100$ and 150 IU nisin/ml as a criterion to choose the more appropriate nisin concentration. Concentrated orange juice $\left(64^{\circ}\right.$ Brix and $\mathrm{pH}$ 3.68) was used. After determining the maximum nisin concentration, a full factorial design with two factors at four levels was used. Factors ranges were: temperatures (92, 95, 98 and $102^{\circ} \mathrm{C}$ ) were selected according to the industrial range for the pasteurization of concentrated orange juice and nisin concentration $(0,5075$ and $100 \mathrm{IU} / \mathrm{ml})$ as shown in Table 1. All samples were treated at $105^{\circ} \mathrm{C}$ for $10 \mathrm{~min}$ to eliminate the presence of possible competitors (12). Nisin used after a storage solution was prepared containing $10^{4} \mathrm{IU} / \mathrm{ml}$ in $\mathrm{HCl}$ $0.02 \mathrm{~N}$, sterilized at $121^{\circ} \mathrm{C}$ for 15 minutes (21). The initial inoculated microbial load of A. acidoterrestris was $10^{6}$ spores $/ \mathrm{ml}$ concentrated orange juice.

Each experiment was performed in duplicate and survivors spores were plate count in $\mathrm{K}$ medium, $\mathrm{pH} 3.7$ with incubation at $43^{\circ} \mathrm{C}$ for 3 to 5 days (26).

Table 1. Factorial design for thermal inactivation for $A$. acidoterrestris CRA 7152

\begin{tabular}{|c|c|c|}
\hline \multirow[t]{2}{*}{ experiment } & \multicolumn{2}{|c|}{ Variable } \\
\hline & ${ }^{\mathrm{a}} \mathbf{T}$ & ${ }^{\mathrm{b}} \mathrm{Ni}(\mathrm{IU} / \mathrm{ml})$ \\
\hline 1 & 92 & 0 \\
\hline 2 & 92 & 50 \\
\hline 3 & 92 & 75 \\
\hline 4 & 92 & 100 \\
\hline 5 & 95 & 0 \\
\hline 6 & 95 & 50 \\
\hline 7 & 95 & 75 \\
\hline 8 & 95 & 100 \\
\hline 9 & 98 & 0 \\
\hline 10 & 98 & 50 \\
\hline 11 & 98 & 75 \\
\hline 12 & 98 & 100 \\
\hline 13 & 102 & 0 \\
\hline 14 & 102 & 50 \\
\hline 15 & 102 & 75 \\
\hline 16 & 102 & 100 \\
\hline
\end{tabular}




\section{Data evaluation and quadratic model}

Data from the survivor's count were use to build survival curves by applying regression of survivors plotted against time in minutes. D values were determined as the negative inverse of the slope of the survivor curve. The $\mathrm{z}$ value was calculated as the negative inverse of the slope of the D $\log$ curve against temperature.

The quadratic model was used to describe the influence of temperature and nisin concentration on the thermochemical resistance. The following model was implemented.

$Y=\beta 0+\beta_{1} X_{1}+\beta_{2} X_{2}+\beta_{3} X_{1}^{2}+\beta_{4} X_{2}^{2}+\beta_{5} X_{1} X_{2}$

Where $\mathrm{X} 1=$ Temperature $\left({ }^{\circ} \mathrm{C}\right) ; \mathrm{X} 2=$ nisin concentration $(\mathrm{IU} / \mathrm{ml}) ; \beta_{0} \ldots \beta_{5}=$ model coefficients; and $\mathrm{Y}=\mathrm{D}$ Valor $(\mathrm{min})$ Analysis of experimental data was done with the Software SAS version 8.0. The given model was statistical validated through analysis of variance. Bias and accuracy factors were also calculated as described by Ross (20).

\section{RESULTS AND DISCUSSION}

\section{Determination of maximum nisin concentration}

Table 2 shows the effect nisin concentrations on $\mathrm{D}$ value at $95^{\circ} \mathrm{C}$ in concentrated juice $\left(64^{\circ} \mathrm{Brix}\right)$. There was a fast decrease in resistance with the addition of $30 \mathrm{IU} / \mathrm{ml}$, which only represents $4.04 \%$ of the resistance obtained in the control $(0 \mathrm{IU} / \mathrm{ml})$, and as the nisin concentration in the juice increased the decrease in the $\mathrm{D}$ value became apparent. This was more evident at concentrations up to $100 \mathrm{IU}(26.22 \%$ of reduction in the $\mathrm{D}$ value), above this value $(150 \mathrm{IU} / \mathrm{ml})$ there was no significant difference of decrease in heat resistance compared to $100 \mathrm{IU} / \mathrm{ml}$, indicating that the increase in the concentration did not improve the ratio of reduction. Komitopoulou et al. (11), using the strain A. acidoterrestris
CRA 7182 in apple juice pH 3.51 and $50 \mathrm{IU} / \mathrm{ml}$, showed reductions around $40 \%$ in the $\mathrm{D}$ value at the lowest temperature of $80^{\circ} \mathrm{C}$ and only $15 \%$ of reduction at $95^{\circ} \mathrm{C}$. Yamazaki et al. (30) reported reduction of 24 and 29\% in the $\mathrm{D}$ value of $A$. acidoterrestris $\mathrm{AB}-5$ at $90^{\circ} \mathrm{C}$ in orange and apple drink respectively.

Table 2. Percentage of reduction in the $\mathrm{D}$ value at $95^{\circ} \mathrm{C}$ with different nisin concentrations in concentrated orange juice.

\begin{tabular}{ccc}
\hline nisin (IU/ml) & D value (min)* & Reduction (\%) \\
\hline 0 & $12.86 \pm 1.2$ & \\
30 & $12.34 \pm 1.0$ & $4.04 \%$ \\
50 & $11.38 \pm 1.1$ & $11.50 \%$ \\
75 & $10.49 \pm 2.0$ & $18.41 \%$ \\
100 & $9.49 \pm 1.5$ & $26.22 \%$ \\
150 & $9.42 \pm 1.0$ & $26.73 \%$ \\
\hline
\end{tabular}

*values are means \pm standard deviations $(\mathrm{n}=2)$

Table 2 shows a tendency for fall in the D value, which was stabilized with approximately $100 \mathrm{IU} / \mathrm{ml}$, a concentration larger than this would incur a larger cost without significant reduction in the $\mathrm{D}$ value.

According to Muriana (15), in most bacteriocin applications the reduction of the bacterial target can be described as moderate; it is assumed that during the thermal treatment all cells are exposed the same temperature, however the macromolecular size of bacteriocins used in foods (4000 to $8000 \mathrm{Da}$ ) physically hinders the bond between molecules to obtain very positive effects. The relatively large size of bacteriocins and their protein character make them susceptible to biochemical reactions that implicate in collateral chains of amino acids or in hydrophobic interactions that can hinder the bonds with the microbial target. Thus, it is possible to assume that after a specific nisin 
concentration, its increase would hinder the "physical space" of entrance of its molecule into the target microorganism, consequently reducing its inhibiting effect.

Thus, $100 \mathrm{IU} / \mathrm{ml}$ was chosen as maximum nisin concentration to be tested in the experiment.

Effect of temperature and nisin concentration on thermal death kinetics of $\boldsymbol{A}$. acidoterrestris

Table 3 shows a summary of D values calculated for the factorial planning of Table 1, with their respective reductions in percentages. The nisin effect becomes more evident as the tested temperature becomes smaller $\left(92^{\circ} \mathrm{C}\right)$. To a same nisin concentration, the sensitivity to heat was more pronounced at low temperatures $\left(92^{\circ} \mathrm{C}\right)$, in which the reduction in the $\mathrm{D}$ value was $29.34,21.38$ and $10.41 \%$ for 100,75 and $50 \mathrm{IU} / \mathrm{ml}$ of nisin concentration, respectively. Komitopoulou et al. (11) found similar results, with the A. acidoterrestris spore sensitivity being more pronounced at smaller temperatures. However, Jeknic et al. (10) showed that there is alteration in nisin activity when it is exposed to high temperatures.

Table 3. Effect of temperature and nisin concentration on the percentage of reduction in $\mathrm{D}$ values of $A$. acidoterrestris CRA 7152 in concentrated orange juice $\mathrm{pH} 3.68$ and $64^{\circ}$ Brix.

\begin{tabular}{cllcccccc}
\hline Nisin (UI/ml) & \multicolumn{2}{c}{$\mathbf{9 2}^{\mathbf{}} \mathbf{C}$} & \multicolumn{2}{c}{$\mathbf{9 5}^{\mathbf{C}}$} & \multicolumn{2}{c}{$\mathbf{9 8}^{\circ} \mathbf{C}$} & \multicolumn{2}{c}{$\mathbf{1 0 2}^{\circ} \mathbf{C}$} \\
\hline & D (min)* & Reduction & D (min)* & Reduction & D (min)* & Reduction & D (min)* & Reduction \\
\hline 0 & $25.56 \pm 3.3$ & & $12.86 \pm 1.5$ & & $6.16 \pm 1.2$ & & $2.01 \pm 0.4$ & \\
50 & $22.9 \pm 3.9$ & $10.41 \%$ & $11.38 \pm 1.3$ & $11.5 \%$ & $5.55 \pm 0.5$ & $9.87 \%$ & $1.83 \pm 0.2$ & $9.14 \%$ \\
75 & $20.10 \pm 4.3$ & $21.38 \%$ & $10.49 \pm 1.9$ & $18.41 \%$ & $5.12 \pm 0.5$ & $16.93 \%$ & $1.64 \pm 0.2$ & $18.43 \%$ \\
100 & $18.06 \pm 2.9$ & $29.34 \%$ & $9.48 \pm 1.6$ & $26.22 \%$ & $4.76 \pm 0.6$ & $22.71 \%$ & $1.59 \pm 0.1$ & $20.70 \%$ \\
\hline
\end{tabular}

*values are means \pm standard deviations $(\mathrm{n}=2)$

A linear behavior was present in all curves, with correlation coefficients $\mathrm{R}^{2}$ between 0.9668 and 0.9960 . Figure 1 shows the survivor curves at $98^{\circ} \mathrm{C}$, where a reduction of $22.71 \%$ was obtained with $100 \mathrm{IU} / \mathrm{ml}$.

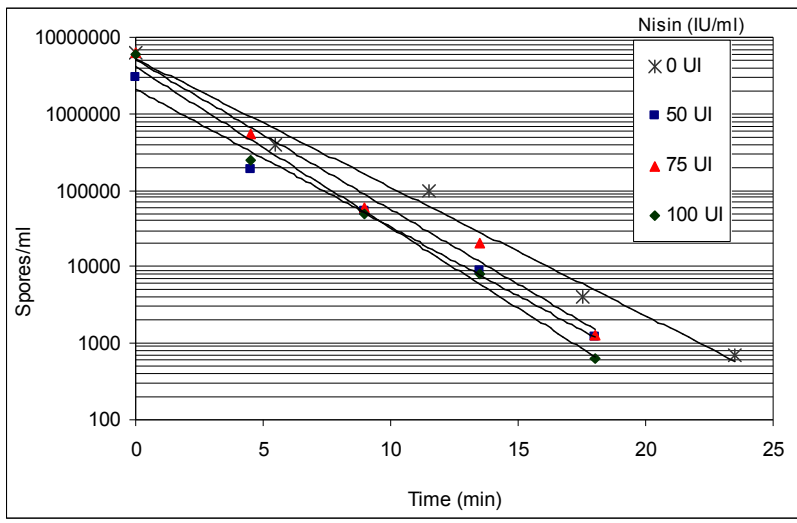

Yamazaki et al. (29) showed that the lysozyme addition (10 ppm) contributed in $30 \%$ to reduce the heat resistance of A. acidoterrestris AB-1 spores in citrate buffer ( $\mathrm{pH} 4.0)$ when compared to the control $(0 \mathrm{ppm})$ heated at $89^{\circ} \mathrm{C}$. Yamazaki et al. (30) managed to reduce the heat resistance of these spores (strain AB-5) to $29 \%$ and $24 \%$ in clarified apple juice and orange drink respectively, when added $200 \mathrm{IU} / \mathrm{ml}$ of nisin. In the present study, the thermal resistance of $A$. acidoterrestris

Figure 1. Nisin effect on survival of $A$. acidoterrestris CRA 7152 spores at $98^{\circ} \mathrm{C} \mathrm{pH} 3.68$ e $64^{\circ}$ Brix. With correlation coefficients $\mathrm{R}^{2} 0.9668,0.9866,0.9865$ and 0.9868 for 0,50 , 75 and $100 \mathrm{IU} / \mathrm{ml}$ nisin respectively. 
CRA 7152 spores was reduced in 29.34, 26.21, 22.71 and $20.70 \%$ at temperatures of $92,95,98$ and $102^{\circ} \mathrm{C}$, respectively, with addition of $100 \mathrm{UI} / \mathrm{ml}$ of nisin. It is observed then, that the inhibiting effect of nisin against $A$. acidoterrestris spores is similar to the effect of lysozyme, however with a different mechanism of action. It is worth to add that the antimicrobial effect of lysozyme will be lost after food pasteurization, as it is heat-labile, whereas nisin has greater stability at high temperatures and in acid pHs (4). In another work, Pontius et al. (18) studied the effect of malic, citric and tartaric acids on the heat resistance of these spores. The authors found that the type of acid was not statistically significant at the studied temperatures $\left(91\right.$ to $\left.97^{\circ} \mathrm{C}\right)$ and high D values were obtained for the strains VF, WAC, and IP, either equal or greater than the ones reported by Splittstoesser et al. (23) for the same strains, which does not add up to heat resistance reduction.

The $\mathrm{z}$ value (Figure 2) was not strongly influenced by the presence of nisin; only an increase up to $0.5^{\circ} \mathrm{C}$ was found $\left(100 \mathrm{IU} / \mathrm{ml}, \mathrm{z}=9.49^{\circ} \mathrm{C}\right)$ when compared with the control $(\mathrm{z}=$ $9.06^{\circ} \mathrm{C}$ ). The $\mathrm{z}$ values for this microorganism in the literature vary from 6.4 (19) to 13.8 (11) depending on the nature of the product (laboratory or food), microorganism strain, $\mathrm{pH}$ and presence or not of preservative.

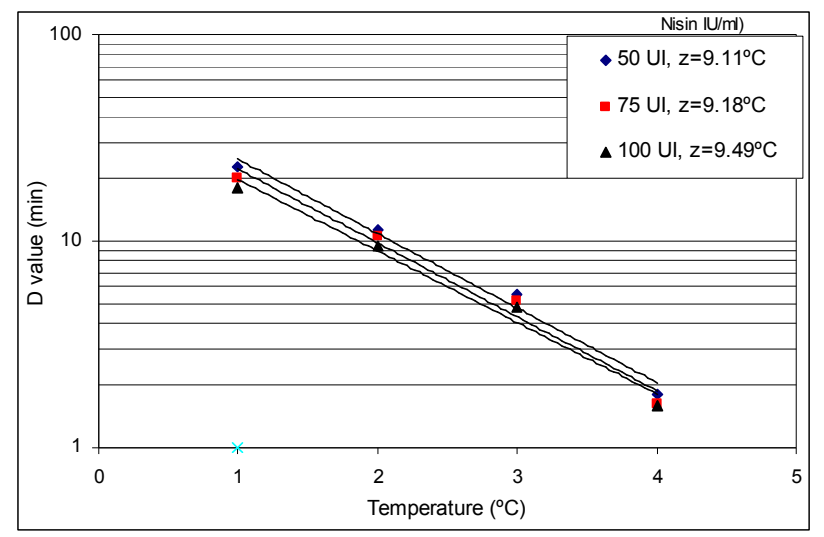

\section{Modeling of $D$ value through quadratic model}

Data related to D values (Table 3) as a function of temperature and nisin concentration were used for modeling response surface and adjusted by non linear regression to the equation 1 model.

Table 4 indicates adjustment coefficient with probability level of 0.05 .

Table 4. Relevant regression coefficients for the polynomial model for $A$. acidoterrestris thermal inactivation in concentrated orange juice.

\begin{tabular}{ccc}
\hline Variable & Coefficient & probability \\
\hline Average & 2081.53 & $<0.0001$ \\
Temperature & -40.3924 & $<0.0001$ \\
Nisin & -0.6982 & 0.0001 \\
Temperature*Nisin & 0.00688 & 0.0002 \\
Temperature $^{2}$ & 0.1961 & $<0.0001$ \\
\hline
\end{tabular}

It is evident that all variables of the table 4 were relevant $(\mathrm{p}<0.05)$. Equation 2 presents the quadratic model achieved:

$$
\begin{aligned}
D= & 2081.5333-40.3924 * T-0.6982 * M+ \\
& 0.00688 * \operatorname{Tem}^{*} N i+0.1961 * \operatorname{Tem}^{2}
\end{aligned}
$$

Where: $\mathrm{D}=\mathrm{D}$ value $(\mathrm{min}) ; \mathrm{Ni}=$ nisin concentration $(\mathrm{IU} / \mathrm{ml}) ;$ Temp $=$ temperature $\left({ }^{\circ} \mathrm{C}\right)$.

Pareto's graphic shown in figure 3 presents standardized effects of the parameters from the model 2. The standardized effect was defined as the estimated coefficient divided by the standard error $\left(b_{i} / s_{i}\right)$. Any other effect that exceeded the

Figure 2. Nisin effect on $\mathrm{z}$ value of $A$. acidoterrestris CRA 7152 in concentrated orange juice $\mathrm{pH} 3.68$ and $64^{\circ}$ Brix. $\mathrm{R}^{2}$ $0.9979,0.9957$ and 0.9964 for 50,75 and $100 \mathrm{IU} / \mathrm{ml}$ nisin respectively. 
vertical line $(\mathrm{p}=0.05)$ was considered significant. Thus, the of importance: $\mathrm{T}, \mathrm{T}^{2}$, Nisin, and $\mathrm{T}^{*} \mathrm{Nisin}$. following factors showed significant effect decreasing order

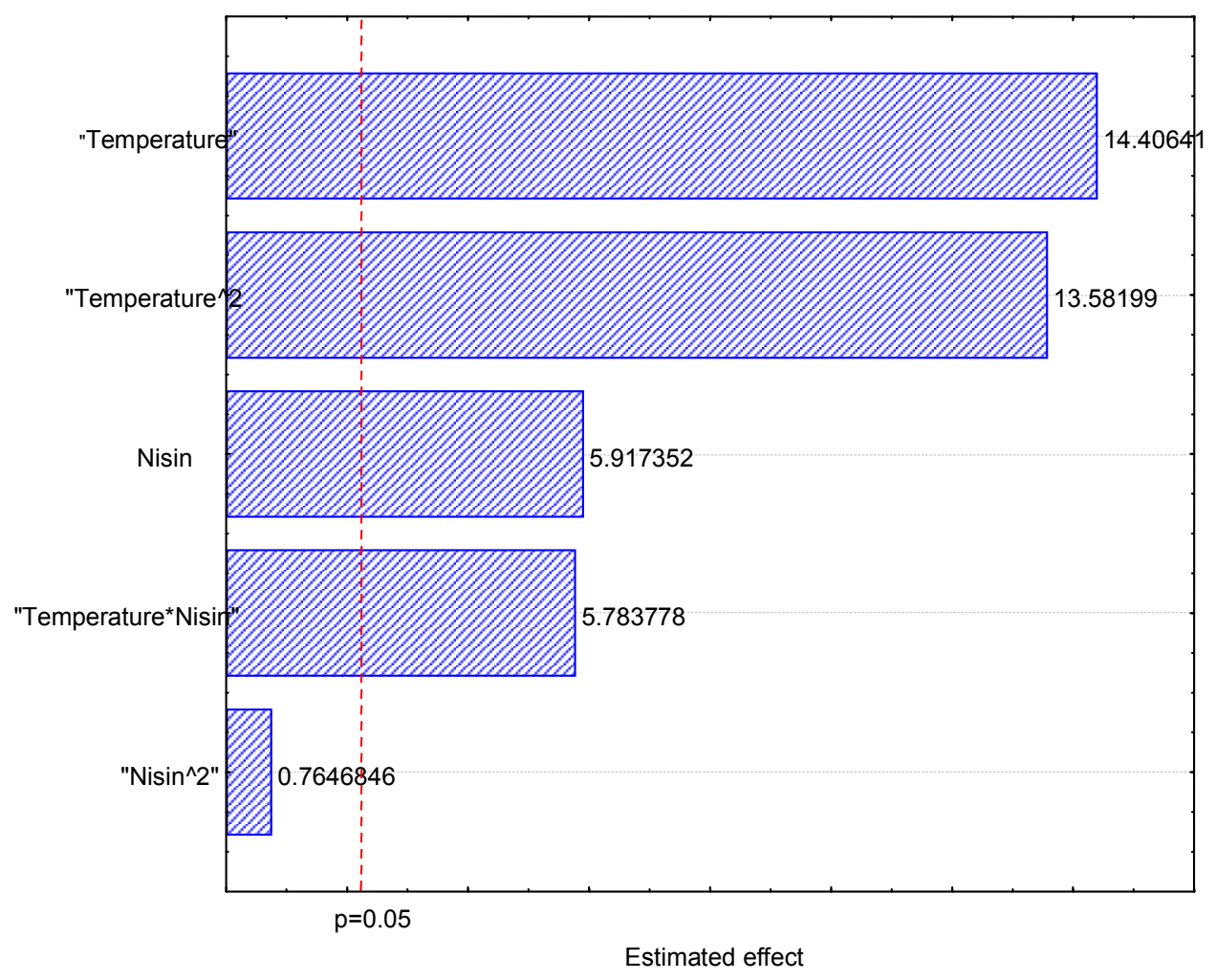

Figure 3. Pareto's graph to evaluate the effect of parameters on thermal inactivation of A. acidoterrestris in concentrated orange juice.

The analysis of variance for the response variable indicated that the model was highly significant $(F 572.7$ and $\mathrm{R}^{2}$ of 0.995$)$. Bias and accuracy factors were 0.999 and 1.089, respectively, not showing systematic tendency in the predictions. Figure 4 shows a graphic comparison between predicted values vs observed values. Note that the predictive model adjust well the results of experiments.

The lack of data in the literature about thermochemical resistance in orange concentrate impairs a deeper discussion of our results. However, it is demonstrated that the found model can be used in the implementation of thermal treatment, aiming at killing $A$. acidoterrestris spores only for concentrated juice under the same conditions of this study. Silva et al. (22) generated a polynomial model to study the effect of soluble solids, $\mathrm{pH}$ and temperature on heat resistance of $A$. acidoterrestris spores using laboratory medium. When the model was applied to food systems (cupuaçu extract and orange juice), it revealed errors up to 
$100 \%$ of difference in the predictions; showing that when the objective is to implement models for specific processes is advisable to generate them from data obtained from the very product in question.

Figure 5 shows $\mathrm{D}$ value response surface. As it was expected, the main impact was temperature. A small temperature increase can cause a significant decrease in D. The $\mathrm{D}$ value decreased slightly with the increase in nisin concentration, mainly at low temperatures. At higher temperatures, such as $100^{\circ} \mathrm{C}$, the addition of $100 \mathrm{IU} / \mathrm{ml}$ or more did not cause greater resistance loss, with a $\mathrm{D}$ value of $1.5 \mathrm{~min}$ at $102^{\circ} \mathrm{C}$.

The curvature on the surface of figure 5 was due to the quadratic effect of the temperature $\left(\mathrm{T}^{2}\right.$ was highly significant). The $\mathrm{D}$ value varied linearly with the increase in nisin concentration.

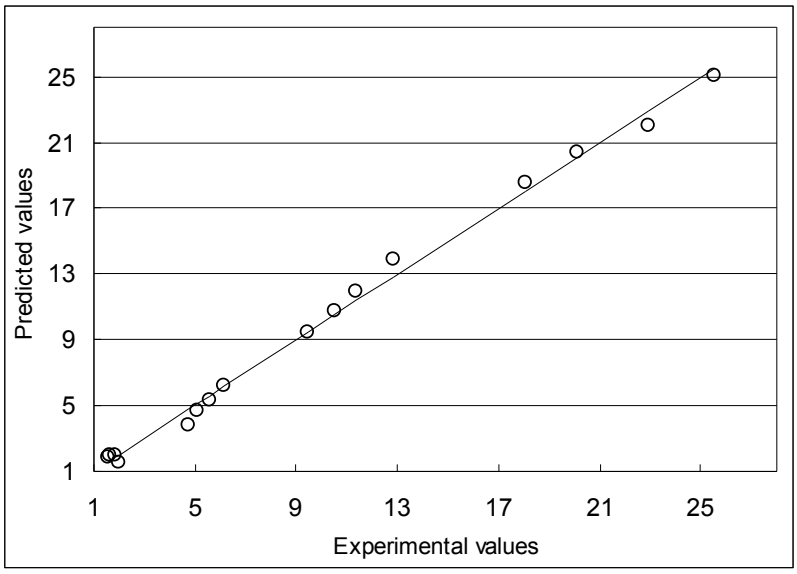

Figure 4. Observed vs predicted values of D values.

\section{Quadratic model verification}

The model was verified by conducting 6 experiments under random combination of temperature and nisin concentration (Table 5). All the experiments verified that the model was valid. Bias factor (1.02) indicated safe predictions and accuracy factor (1.15) showed deviation of only $15 \%$. Thus, the results of experiments 1, 2, 3 and 4 indicated that the model prediction "fail safe" and experiment 5 and 6 suggested a slight over prediction by this model. These experiments (Table 5) show that the use of nisin can help to reduction thermal resistance of Alicyclobacillus spores.

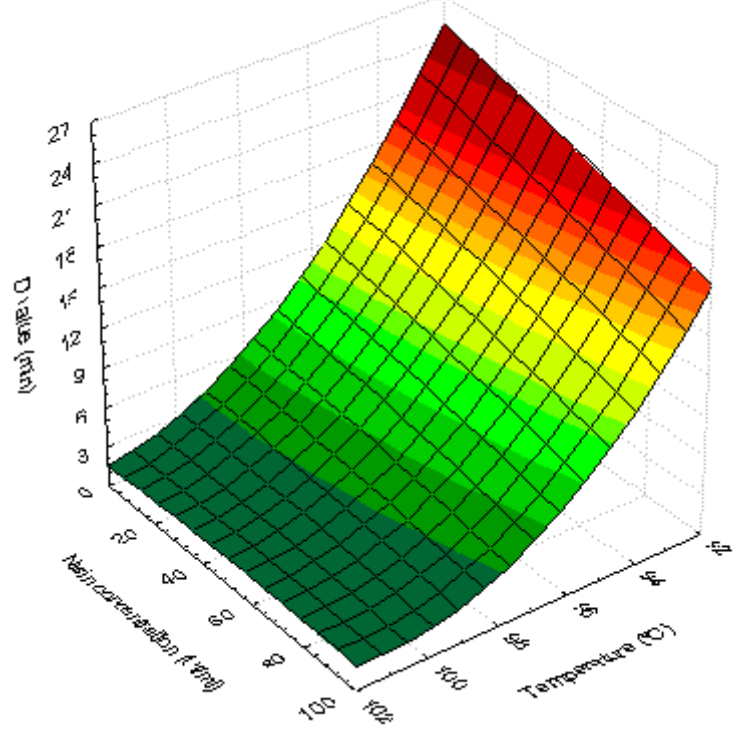

Figure 5. Response surface for $\mathrm{D}$ value of $A$. acidoterrestris in concentrated orange juice

Table 5. Verification trials of response surface model for D value of $A$. acidoterrestris in concentrate orange juice

\begin{tabular}{ccccc}
\hline Trial & Temperature & $\begin{array}{c}\text { Nisin } \\
\text { concentration }\end{array}$ & $\begin{array}{c}\text { Predicted } \\
\text { D value } \\
\text { (min) }\end{array}$ & $\begin{array}{c}\text { Observed } \\
\text { D value } \\
\text { (min) }\end{array}$ \\
\hline $\mathbf{n}^{\mathbf{0}}$ & ${ }^{\mathbf{o}} \mathbf{C}$ & $(\mathbf{I U} / \mathbf{m l})$ & 11.12 & 11.04 \\
1 & 96 & 0 & 9.23 & 9.21 \\
2 & 96 & 50 & 7.35 & 7.34 \\
3 & 96 & 100 & 3.29 & 3.14 \\
4 & 100 & 0 & 2.78 & 2.87 \\
5 & 100 & 50 & 2.27 & 2.39 \\
6 & 100 & 100 & & \\
\hline
\end{tabular}


The importance of the present research was to show that the incorporation of nisin into the juice during heating increased microorganism sensitivity resulting in an increase of lethality of the pasteurization. Considering that nisin is a non-toxic preservative $(8,9)$ in the conditions of use in foods, it can be used and perceived as a natural preservative, satisfying the consumer demand for natural foods. Its utilization as part of a multi-barrier system becomes therefore of interest. The main drawback of its use as an aid to the thermal treatment is that some nisin is lost due to heating and the interactions with food characteristics such as $\mathrm{pH}, \mathrm{Aw}$, etc (25). As a result, the levels of nisin addition should be adjusted to compensate for this loss. During cheese processing, for instance, there is a typical 15 to $20 \%$ loss depending on the intensity of the applied thermal treatment and the $\mathrm{pH}$ of the product, seeing that the best retention is obtained in acid $\mathrm{pH}$. In the case of UHT processing, the loss of nisin activity can reach up to $40 \%$. However, after the processing, few spores remained and smaller amount of residual nisin may be required considering the effect of temperature individually. Besides, the UHT treatments injure the spores, turning them more sensitive to nisin (6).

The results lead to the conclusion that the $\mathrm{D}$ values of $A$. acidoterrestris obtained in concentrated juice were shown much larger than the ones found in the literature for simple juices.

Nisin is an alternative aid to thermal treatment for the reduction in heat resistance of $A$. acidoterrestris spores, with $29 \%, 26 \%, 23 \%$ and $21 \%$ of reduction in the D value at 92 , 95,98 and $102^{\circ} \mathrm{C}$ respectively, when $100 \mathrm{IU}$ of nisin/ml were incorporated into the juice. Higher concentrations do not modify this result.

The generated quadratic model gave a suitable description of the $\mathrm{D}$ value data as a function of temperature and nisin concentration, having the temperature as main factor followed by nisin concentration. Both factors showed linear dependence, whereas only temperature showed quadratic dependence. The obtained results can have practical application for the citric juice processing industry.

\section{ACKNOWLEDGMENTS}

To Fapesp - São Paulo State Research Foundation (Fundação de Amparo à Pesquisa do Estado de São Paulo) for the financial support. SucoRico S.A. for supplying concentrated orange juice. Danisco Cultor Brazil for supplying nisin.

\section{RESUMO}

\section{Modelagem microbiana da resistência térmica de esporos de Alicyclobacillus acidoterrestris CRA7152 em suco de laranja concentrado com adição de nisina}

Estudou-se o efeito da nisina na inativação térmica dos esporos de Alicyclobacillus acidoterrestris CRA 7152 em suco de laranja concentrado (64 ${ }^{\circ}$ Brix). Foram avaliadas as concentrações de 0, 50, 75 e $100 \mathrm{UI}$ de nisina/ml de suco nas temperaturas de $92,95,98$ e $102{ }^{\circ} \mathrm{C}$. Foi utilizado o modelo polinomial quadrático para analisar os efeitos dos fatores e suas interações. A contagem dos esporos sobreviventes foi feita através de plaqueamento em meio $\mathrm{K}(\mathrm{pH}=3,7)$. De acordo com os resultados obtidos encontrou-se um valor de D sem adição de nisina de 25,5;12,9;6,1 e 2,3 min para as temperaturas de $92,95,98$ e $102{ }^{\circ} \mathrm{C}$ respectivamente. Quando a nisina foi adicionada ao suco observou-se uma queda na resistência térmica em função do aumento da concentração de nisina para os mesmos valores de temperatura. Ao utilizar as concentrações de $30,50,75$ e $150 \mathrm{IU} / \mathrm{ml}$ a $95^{\circ} \mathrm{C}$, o valor de 
D obtido foi de 12,$34 ; 11,38 ; 10,49 ; 9,49$; e 9,42 $\min$ respectivamente demonstrando que a adição de nisina provoca um decréscimo de até $27 \%$ no valor de D. O modelo polinomial de segunda ordem ajustado com $r^{2}=0,995$ mostrou que a resistência do microorganismo foi afetada pela temperatura seguida da concentração de nisina. A adição de nisina é, portanto, uma alternativa para reduzir o rigor do tratamento térmico em $A$. acidoterrestris CRA 7152.

Palavras-chave: Alicyclobacillus acidoterrestris, suco de laranja concentrado, modelagem, nisina

\section{REFERENCES}

1. Adams, M.; Nizo, E.S. (2007). Nisin in multifactorial food preservation. chapter 2, In: Sibel Roller, Natural antimicrobials for the minimal processing of foods, CRC, Boston.

2. Beard, B.M.; Sheldon, B.W.; Foegeding, P.M. (1999). Thermal resistance of bacterial spores in milk-based beverage $4 \mathrm{~s}$ supplemented with nisin. J. food protect $62,484-491$.

3. Blocher, J.C.; Busta, F.F. (1983). Bacterial spore resistance to acid. Food Technol, November, 87-99.

4. Davies, E.A.; Bevis, H.E.; Potter, R.; Harris, J.; Williams, G.C.; Delves-Broughton. J. (1998). The effect of $\mathrm{pH}$ on the stability of nisin solution during autoclaving. Lett. Appl. Microbiol, 27, 186-187.

5. Delves-Broughton, J. (1990). Nisin and its uses as a food preservative. Food Technol. 44(11), 100-117.

6. Delves-Broughton, J.; Blackburn, P.; Evans, R.E.; Hugenholtz, J. (1996). Applications of the bacteriocin, nisin. Anton. Von. Leuwen, 69, 193-202.

7. Eiroa, M.N.V.; Junqueira, V.C.A.; Schmidt, F. (1999). Alicyclobacillus in orange juice: occurrence and heat resistance of spores. J. food protect. $62(8), 883-886$.

8. Franco, B.G.M.; Landraf, M. (2003). Microbiologia dos Alimentos, (Editora Atheneu), São Paulo.

9. Jay, J.M. (1994). Microbiologia moderna de los Alimentos, tercera edición, (Editorial Acribia) Zaragoza España.

10. Jeknic, T.M.; Gould, S.E.; Daeschel, M.A. (1996). Structural analysis of thermally inactivated nisin. IFT annual meeting: book of abastracts, p.30 ISSN 1082-1236.
11. Komitopoulou, E.; Boziaris, I.S.; Davies, E.A.; Delves-Broughton, J.; Adams, M.R. (1999). Alicyclobacillus acidoterrestris in fruit juices and its control by nisin. J. Food Sci. and Technol. 34, 81-85.

12. Massaguer, P.R.; Pacheco, P.C.; Atarassi, M.M.; Peña, W.L.; Gonçalves, A.C.; Paula, N.A.; Geraldini, L.H.; Liossi, L.L.; Gagliazzi, M.R.; Guerra, V.A. (2002). Sensibility and Specifity of Methods for Alicyclobacillus Detection and Quantification: A collaborative study. Fruit Processing 11, 478-482.

13. Mc KNIGHT, I.C.S. (2003). Isolamento $e$ identificação de Alicycclobacillus acidoterrestris a partir de sucos de maracujá e abacaxi pasteurizados, e determinação da resistência térmica de seus esporos (Ds. Tese de doutorado da Faculdade de Engenharia de Alimentos - Unicamp).

14. Murakami, M.; Tedzuka, H.; Yamazaki, K. (1998). Thermal resistence of Alicyclobacillus acidoterrestris spores in different buffers and $\mathrm{pH}$. Food Microbiol. 15, 577-582.

15. Muriana, P.M. (1996). Bacteriocins for control of Listeria spp. In Food. J. Food Protect., supplement, 54-63.

16. Penna, T.C.V.; Moraes, D.A. (2002). The influence of nisin on the thermal resistance of bacillus cereus. J. food protect 65 , 415-418.

17. Pinhatti, M.E.M.C.; Variane, S.; Eguichi, S.V.; Manfio, G.P. (1997) Detection of acidothermophilic bacilli in industrialized fruit juices. Fruit processing 9, 350-353.

18. Pontius, A.J.; Rushing, J.E.; Foegeding, P.M. (1998). Heat resistance of Alicyclobacillus acidoterrestris spores as affected by varius $\mathrm{pH}$ values and organic acids. $J$. food protect $16(1), 41-46$

19. Previdi, M.P.; Quintavalla, S.; Lusardi, C.; Vicini, E. (1997). Heat resistance of Alicyclobacillus spores in fruit juices. Indust. Conserve $72,353-358$.

20. Ross, T. (1996). Indices for performance evaluation of predictive models in food microbiology. J. Appl. Bacteriol. 81, 501-508.

21. Scott, V.N.; Taylor, S.L. (1981). Temperature, pH and spore load effects on the ability of nisin to prevent the outgrowth of $C$. botulinum spores. J. food Sci. 46, 121-125.

22. Silva, F.M.; Gibbs, P.; Margarida, C.V.; Silva, C.L.M. (1999). Therma inactivation of Alicyclobacillus acidoterrestris spores under different temperature, soluble solids and $\mathrm{pH}$ conditions for the design of fruit processes. Int. J. Food Microbiol. 51, 95-103.

23. Splittstoesser, D.F.; Churey, J.J.; Lee, Y. (1994). Growth characteristics of aciduric sporeforming Bacilli isolated from fruit juices. J. Food Protect. 57, 1080-1083.

24. Stumbo, C.R. (1973). Thermobacteriology in food processing, Academic press, New York, 236p. 
25. Thomas, L.V.; Clarkson, M.R.; Delves-Broughton, J. (2000). Nisin chapter 18, In: Natural food antimicrobial system edited by Naidu, A.S. CRC press London.

26. Walls, I.; Chuyate, R. (1998). Alicyclobacillus-Historical perspective and preliminary characterization study. Dairy, Food and environ. Sanit. 18(8), 499-503.

27. Walls, I.; Chuyate, R. (2000). Spoilage of fruit juice by Alicyclobacillus acidoterrestris. Food Aus. v(7), 286-288.

28. Wandling, L.R.; Sheldon, B.W.; Foegeding, P.M. (1999). Nisin in milk sensitizes bacillus spores to heat and prevent recovery of survivors. $J$ food protect. $62,492-498$.

29. Yamazaki, K.; Isoda, C.; Hedzuka, H.; Kawai, Y.; Shinano, H. (1997). Thermal resistance and prevention of spoilage bacterium, Alicyclobacillus acidoterrestris in acidic beverages. Nipon Shokunin, Kagakun Kaishin. 44, 905-911.

30. Yamazaki, K.; Murakami, M.; Kawi, Y.; Inoue, N.; Matsuda, T. (2000). Use of nisin for inibition of Alicyclobacillus acidoterrestris in acidic drinks. F. microbial. 17, 315-320. 